\title{
PROSPECTIVE STUDY OF LIPID PROFILE IN DIFFERENT STAGES OF DIABETES
}

\author{
Indira Bhaskar Biswas ${ }^{1}$, Chittaranjan Maity²
}

${ }_{1}^{1}$ Associate Professor, Department of Biochemistry, KPC Medical College \& Hospital, Jadavpur, Kolkata.

2Professor \& HOD, Department of Biochemistry, KPC Medical College \& Hospital, Jadavpur, Kolkata.

\section{ABSTRACT}

Diabetes mellitus is increasing worldwide. This study was undertaken to evaluate the lipid profile among HbA1c (Glycated haemoglobin) in Type 2 diabetes and correlation of higher values of HbA1c with risk of Cardiovascular disease. The study was conducted in KPC Medical College and Hospital; 230 patients diagnosed of Type 2 diabetes aged between 21-90 years. These patients were divided into 3 groups based on their HbA1c values as controlled, under-controlled and uncontrolled diabetes. The glycated haemoglobin and lipid profile were recorded with standard procedure. Data was analysed statistically. Total number of cases were 230, males 104 and females 126. Uncontrolled diabetes had significantly high values of lipid profile. From our results, we concluded that high HbA1c have increased risk of Cardiovascular Disease.

\section{KEYWORDS}

Lipid profile, HbA1c, Diabetes, CVD.

HOW TO CITE THIS ARTICLE: Biswas IB, Maity C. Prospective study of lipid profile in different stages of diabetes. J. Evolution Med. Dent. Sci. 2016;5(22):1160-1164, DOI: 10.14260/jemds/2016/270

\section{INTRODUCTION}

Diabetes mellitus is increasing worldwide and India is likely to be the diabetes capital in the near future. It was noted in the year 2014, 387 million people were estimated to have diabetes worldwide. ${ }^{1}$ out of which type 2 diabetes was $90 \%{ }^{2,3}$ During 2012-2014, diabetes was estimated to have resulted in 1.5-4.9 million deaths each year. ${ }^{4}$ And the number of people with diabetes is expected to rise to 592 million by 2035.2 Diabetes is a group of metabolic disease, in which there is high blood sugar level over a prolonged period. ${ }^{5}$

It is classified according to WHO recommendation in 1999. Type $1 \mathrm{DM}$ is $5 \%$ and is due to decreased insulin production. In Type $2 \mathrm{DM}$, which is $95 \%$ due to insulin resistance which may be combined with relatively reduced insulin secretion or both. ${ }^{6}$ Symptoms of diabetes include frequent urination, increased thirst and increased hunger.

It leads to complication if not treated; acute complications include DKA and non-ketotic hyperosmolar coma and long-term complications include cardiovascular disease, stroke, chronic kidney failure, foot ulceration and damage to the eyes. ${ }^{7}$ Diabetes doubles the risk of cardiovascular disease and $75 \%$ of the deaths are due to coronary artery disease. ${ }^{8} \mathrm{CAD}$ is characterized by plaque deposits of lipids. Fibrous connective tissue, calcium, hyperglycaemia and atherosclerosis are related, in turn it develops myocardial infarction which is the leading cause of morbidity and mortality worldwide. 9,10

The objective of this study was to know the lipid profile among different diabetic groups and to evaluate the association between glycated haemoglobin and lipid profile.

Financial or Other, Competing Interest: None.

Submission 04-02-2016, Peer Review 29-02-2016,

Acceptance 05-03-2016, Published 16-03-2016.

Corresponding Author:

Dr. Indira Bhaskar Biswas,

Department of Biochemistry,

KPC Medical College \& Hospital,

$1 F$, Raja SC Mullick Road,

Jadavpur -700032,

Kolkata.

E-mail: indu170@rediffmail.com

DOI: $10.14260 /$ jemds $/ 2016 / 270$

\section{MATERIALS AND METHODS}

Two hundred and thirty Type 2 diabetes patients were taken in this cross-sectional study. The study was carried out in the Department of Biochemistry and Endocrinology, KPC Medical College and Hospital, Kolkata. Patients included were aged between 21-90 years and both sexes from inpatients as well as outpatients of our institution. Diagnosed with type 2 diabetes according to American Diabetes Association 2009 criteria and $\mathrm{HbA} 1 \mathrm{c}>6.5 \%$ were included in the study. Informed consent was obtained from all the cases. The study protocol was approved by the Institutional Ethical Committee. Exclusion criteria were Type I DM, latent immune diabetes of the adult, gestational diabetes, neoplasms as well as any major medical conditions in the 6 months preceding the study (Liver, kidney/heart failure, etc.) also subjects taking hypolipidaemic drugs also excluded.

Clinical data was collected from all subjects. Weight and height were measured, BMI calculated $(\mathrm{kg} / \mathrm{m} 2)$. Whole blood with aseptic precaution was drawn after an overnight fast. HbA1c measured by Biorad D-10 and lipid profile which includes total cholesterol, triglyceride, HDL-C were assayed using enzymatic methods Shenzhen Mindray, Biomedical Electronics Co. Ltd. LDL was calculated using Friedewald's formula. ${ }^{11}$

\section{Statistical Analysis}

Data was analysed using the Statistical Package for Social Sciences (SPSS) version 22.

Descriptive statistics were performed to tabulate the distribution of mean value of glycated haemoglobin and lipid profile. ANOVA test is applied to know the significance between groups and multiple comparisons was by Bonferroni.

\section{RESULTS}

In our study, 230 cases of Type 2 DM were included. Age ranged from 21-90 yrs. and majority of cases were in the age group of 61-70 yrs., i.e. $74(32.2 \%)$ cases and 51-60 yrs. there were 67 (29.1\%) cases shown in the Figure 1.

Out of 230 cases diagnosed of Type 2 diabetes 104 (45.2\%) were males and 126 (54.8\%) females. HbA1c values 
$>6.5 \%$ were included and all the cases were divided into 3 groups depending on the $\mathrm{HbA} 1 \mathrm{c}$ values, as controlled diabetic HbA1c 6.5-7\%, under controlled diabetic HbA1c >7-8\% and uncontrolled diabetic HbA1c $>8 \%$. Out of 230 cases control diabetic were 119 (51.7\%) cases, under control diabetic 37 (16.1\%) and uncontrolled diabetic were 74 (34.2\%) cases. The lipid profile assayed were total cholesterol, triglyceride, LDL, HDL, VLDL in all the 3 groups, total cholesterol $>200$ $\mathrm{mg} / \mathrm{dL}$ were $48(22.3 \%)$ cases and $<200 \mathrm{mg} / \mathrm{dL} 182(78.7 \%)$. Triglyceride $>150 \mathrm{mg} / \mathrm{dL}$ were $64(27.8 \%)$ and $<150 \mathrm{mg} / \mathrm{dL}$ $166(72.2 \%)$ cases, LDL $>100 \mathrm{mg} / \mathrm{dL}$ were 87 (37.8\%) and $143(162.2 \%)$ were $<100 \mathrm{mg} / \mathrm{dL}$. HDL-c $<40 \mathrm{mg} / \mathrm{dL}$ in males and $<50 \mathrm{mg} / \mathrm{dL}$ in females were $64(27.8 \%)$ and 97 (42.2\%) and HDL-c $>40 \mathrm{mg} / \mathrm{dL}$ and $>50 \mathrm{mg} / \mathrm{dL}$ in male and female were $40(17.4 \%)$ and 29 (12.6\%). Mean with SD and the distribution of different glycated haemoglobin groups with various lipid profile is shown in the Table 1,2 and 3.

\section{DISCUSSION}

Diabetes is fast gaining the status of potential epidemic in India with more than 62 million diabetic individuals currently diagnosed.12,13 Effective glycaemic control is associated with reduced risk of complications of Type 1 and 2 Diabetes.14-16 Patients who establish and maintain good control early in the course of the disease may have reduced risk of microvascular and macrovascular complications of diabetes over a period of years to decades. ${ }^{15-17}$

In the present study 230 patients were Type $2 \mathrm{DM}$, HbA1c $>6.5 \%$ which is the gold standard test was used according to the diabetic complications and control trial, which is the standard for glycaemic control. The diabetic patients with higher $\mathrm{HbA} 1 \mathrm{c}>7 \%$ can exhibit a significant increase in lipid profile and level of $\leq 7 \%$ was said to be appropriate for reducing the risk of cardiovascular complications. ${ }^{18}$ Hence, we divided our subjects into 3 groups to study the risk of complications of Type $2 \mathrm{DM}$.

Lipid abnormalities are common in Type 2 DM. Khan et al. reported that severity of dyslipidaemia increased in patients with higher HbA1c value. ${ }^{19}$ Some authors stated mild $<7 \%$ individuals often exhibit atherogenic pattern of risk factors that include higher level of total cholesterol, LDL, TGs and lower level of HDL than individuals who do not develop diabetes. Out of 230 patients, $69.6 \%$ have one or more lipid abnormalities, while the prevalence of diabetic dyslipidaemia varies from $25-60 \%$ in some studies. ${ }^{20}$ According to Khurshed et al. it is reported as $72 \% .^{21}$ The variation in prevalence may be due to genetic variation or BMI.

Age groups included were between $21-90$ yrs., but most of our patients were between $61-70$ yrs., that is $74(32.2 \%)$ cases, this may be due to sedentary lifestyle. Dietary fat has long been implicated as a driver of Insulin resistance. Sedentary lifestyle increases the likelihood of development of insulin resistance. ${ }^{22}$

The defects in Insulin Resistance leads to: $\downarrow$ glucose uptake by peripheral tissues (Muscle), $\uparrow$ hepatic glucose production $\downarrow$ (Gluconeogenesis), defect in incretin hormone $\rightarrow$ to
(Gluconeogenesis), defect in incretin hormone $\rightarrow$ to postprandial insulin release by the $\beta$ cells accompanied by failure to suppress glucagon by the $\alpha$ cells $\rightarrow$ in postprandial hyperglycaemia and continued release of glucose from hepatic glycogen stores (Glycogenolysis). ${ }^{23}$

The TGs and VLDL are the most common alteration in Type 2 DM.24 Robert S Dinsmoor stated that the levels of TGs are also associated with an increased risk of heart disease. In this study, TGs and VLDL were significant $(\mathrm{p}<0.001)$ by ANOVA as well as by ' $t$ ' test (Paired sample ' $t$ ' test). Due to increase flow of substrates particularly glucose, fatty acids to liver or defect in the clearance of VLDL-TG that parallels the degree of hyperglycaemia, decrease in LPL activity especially with moderate-to-severe hyperglycaemia who exhibit both insulin deficiency and insulin resistance which results in decreased clearance of VLDL. ${ }^{24}$ LDL is significant $(p<0.05)$.

Howard et al. reported in their study that LDL appears to be a very potent contributor to the development of coronary heart disease and the LDL-C level was the most significant predictor of increased CAD despite an average LDL level of approx. $115 \mathrm{mg} / \mathrm{dL}$, in their study LDL was at levels as low as $70 \mathrm{mg} / \mathrm{dL}$ in diabetics. ${ }^{25}$ LDL in DM individuals have been shown to be more readily oxidised. These particles are believed to play a major role in stimulating atherosclerotic process because of their recognition by macrophage receptors and small dense LDL's are more readily glycated and oxidised. Thus, it may represent an important mechanism by which atherogenesis is increased in Type 2 DM. ${ }^{24} 69.1 \%$ showed decrease in HDL in our study, but is not significant and not a marker for assessment of cardiovascular complications in DM. HDL carries cholesterol from tissues to circulation; it may be that the deposition of LDL and TG are much higher than the amount of HDL, hence not sufficient to transport all the LDL from tissues to circulation. And even sedentary lifestyle, lack of exercise will decrease HDL concentration which goes in favour of our study ( $>60$ yrs. age). Also impaired VLDL catabolism and decreased LPL activity has been shown to be correlated with $\downarrow$ HDL concentration in patients with Type $2 \mathrm{DM} \uparrow$ in Hepatic lipase activity plays a key role in metabolism of HDL also $\downarrow$ HDL concentration. Cholesterol is increased in $21.3 \%$ of the cases, it is insignificant, may be due to diet.

\section{CONCLUSION}

Two large scale studies the UK Prospective Diabetes Study (UKPDS) and Diabetes Control and Complications Trial (DCCT) demonstrated that improving HbA1c by $1 \%$ cuts the risk of microvascular complications by $25 \%$ and $16 \%$ less likely to suffer heart failure. Our study has shown that higher the HbA1c value higher is the risk for complications. So early diagnosis, control of $\mathrm{HbA1c}$ level at the earliest, by change in lifestyle such as diet, physical activity, weight loss and if necessary pharmacological interventions that should aim to achieve maximal benefits in both complication reduction and quality of life while minimizing harm. 


\begin{tabular}{|c|c|c|c|c|c|}
\hline $\mathrm{HbA1c} N=230$ & $\begin{array}{c}\text { Control } \\
6.5-7 \% \\
\mathrm{~N}=119(51.7 \%) \\
\end{array}$ & 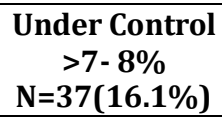 & $\begin{array}{c}\text { Uncontrolled } \\
>8 \% \\
\mathrm{~N}=74(32.2 \%) \\
\end{array}$ & X2 Test & P value \\
\hline $\begin{array}{c}\text { Total - } \mathrm{CH}(\mathrm{mg} / \mathrm{dL}) \\
<200 \\
>200\end{array}$ & $\begin{array}{l}98(42.6 \%) \\
21(9.56 \%)\end{array}$ & $\begin{array}{l}29(12.6 \%) \\
08(3.47 \%)\end{array}$ & $\begin{array}{l}55(23.9 \%) \\
19(8.26 \%)\end{array}$ & 1.8 & $>0.05$ \\
\hline $\begin{array}{c}\text { Triglycerides }(\mathrm{mg} / \mathrm{dL}) \\
<150 \\
>150 \\
\end{array}$ & $\begin{array}{l}94(30.86 \%) \\
25(10.86 \%) \\
\end{array}$ & $\begin{array}{c}26(11.3 \%) \\
11(4.8 \%)\end{array}$ & $\begin{array}{c}46(20 \%) \\
28(12.17 \%) \\
\end{array}$ & 6.51 & $<0.05^{*}$ \\
\hline $\begin{array}{c}\text { HDL-Cholesterol }(\mathrm{mg} / \mathrm{dL}) \\
\text { Male }<40>40 \\
\text { Female }<50>50\end{array}$ & $\begin{array}{c}27(11.7 \%) \\
21(9.1 \%) \\
54(23.47 \%) \\
15(6.52 \%) \\
\end{array}$ & $\begin{array}{l}11(4.78 \%) \\
08(3.47 \%) \\
10(4.35 \%) \\
05(2.17 \%) \\
\end{array}$ & $\begin{array}{c}26(11.3 \%) \\
11(4.78 \%) \\
33(14.34 \%) \\
09(3.91 \%) \\
\end{array}$ & 5.21 & $>0.05$ \\
\hline $\begin{array}{c}\text { LDL-Cholesterol }(\mathrm{mg} / \mathrm{dL}) \\
<100 \\
>100\end{array}$ & $\begin{array}{c}83(36.1 \%) \\
36(15.65 \%)\end{array}$ & $\begin{array}{l}22(9.56 \%) \\
15(6.52 \%)\end{array}$ & $\begin{array}{l}38(16.53 \%) \\
36(15.65 \%)\end{array}$ & 6.7 & $<0.05^{*}$ \\
\hline
\end{tabular}

*-Significant

\begin{tabular}{|c|c|c|c|c|c|}
\hline & & $\mathbf{n}$ & Mean & Std. Deviation & 95\% C.I \\
\hline \multirow[t]{4}{*}{ HbA1c } & 1-control & 119 & 6.724 & .20570 & \multirow{4}{*}{$\begin{array}{c}6.56 \text { to } 6.88 \\
7.27 \text { to } 7.42 \\
9.71 \text { to } 10.53 \\
7.25 \text { to } 7.81\end{array}$} \\
\hline & $\begin{array}{c}\text { 2-under } \\
\text { control }\end{array}$ & 37 & 7.3432 & .23039 & \\
\hline & 3-uncontrolled & 74 & 10.1230 & 1.77058 & \\
\hline & Total & 230 & 7.5270 & 2.15408 & \\
\hline \multirow[t]{4}{*}{ TG } & 1-control & 119 & 119.3950 & 49.63907 & \multirow{4}{*}{$\begin{array}{c}110.38 \text { to } 128.41 \\
104.27 \text { to } 142.16 \\
140.46 \text { to } 177.81 \\
124.39 \text { to } 141.197\end{array}$} \\
\hline & $\begin{array}{c}\text { 2-under } \\
\text { control }\end{array}$ & 37 & 123.2162 & 56.83071 & \\
\hline & 3-uncontrolled & 74 & 159.1351 & 80.62382 & \\
\hline & Total & 230 & 132.7957 & 64.66728 & \\
\hline \multirow[t]{4}{*}{ Total-CH } & 1-control & 119 & 152.4958 & 43.61151 & \multirow{4}{*}{$\begin{array}{l}144.58 \text { to } 160.41 \\
142.52 \text { to } 175.43 \\
152.63 \text { to } 180.67 \\
151.50 \text { to } 164.68\end{array}$} \\
\hline & $\begin{array}{l}\text { 2-under } \\
\text { control }\end{array}$ & 37 & 158.9730 & 49.34993 & \\
\hline & 3-uncontrolled & 74 & 166.6486 & 60.50845 & \\
\hline & Total & 230 & 158.0913 & 50.69616 & \\
\hline \multirow[t]{4}{*}{ LDL } & 1-control & 119 & 87.1008 & 38.18940 & \multirow{4}{*}{$\begin{array}{c}80.17 \text { to } 94.03 \\
76.07 \text { to } 106.09 \\
84.36 \text { to } 07.45 \\
84.95 \text { to } 96.20\end{array}$} \\
\hline & $\begin{array}{c}\text { 2-under } \\
\text { control }\end{array}$ & 37 & 91.0811 & 45.00641 & \\
\hline & 3-uncontrolled & 74 & 95.9054 & 49.82027 & \\
\hline & Total & 230 & 90.5739 & 43.32039 & \\
\hline \multirow[t]{4}{*}{ HDL } & 1-control & 119 & 41.6134 & 9.74428 & \multirow{4}{*}{$\begin{array}{l}39.84 \text { to } 43.38 \\
40.90 \text { to } 46.06 \\
37.32 \text { to } 42.39 \\
40.06 \text { to } 42.63\end{array}$} \\
\hline & $\begin{array}{l}\text { 2-under } \\
\text { control }\end{array}$ & 37 & 43.4865 & 7.74461 & \\
\hline & 3-uncontrolled & 74 & 39.8514 & 10.93653 & \\
\hline & Total & 230 & 41.3478 & 9.89865 & \\
\hline \multirow[t]{4}{*}{ VLDL } & 1-control & 119 & 23.7731 & 9.96046 & \multirow{4}{*}{$\begin{array}{l}21.97 \text { to } 25.58 \\
20.66 \text { to } 28.15 \\
27.78 \text { to } 34.81 \\
24.67 \text { to } 7.92\end{array}$} \\
\hline & $\begin{array}{l}\text { 2-under } \\
\text { control }\end{array}$ & 37 & 24.4054 & 11.22116 & \\
\hline & 3-uncontrolled & 74 & 31.2973 & 15.16189 & \\
\hline & Total & 230 & 26.2957 & 12.49662 & \\
\hline \multicolumn{6}{|c|}{ Table 2: Descriptive Analysis } \\
\hline
\end{tabular}




\begin{tabular}{|c|c|c|c|c|}
\hline & & & $\mathbf{F}$ & Sig. \\
\hline \multirow{2}{*}{$\mathrm{HbA1c}$} & \multirow{2}{*}{$\begin{array}{l}\text { HbA1c Between Groups } \\
\text { Unweighed }\end{array}$} & & 326.568 & $<0.001^{*}$ \\
\hline & & & 651.904 & $<0.001^{*}$ \\
\hline \multirow{2}{*}{ TG } & \multirow{2}{*}{$\begin{array}{l}\text { TG Between Groups } \\
\text { Unweighed }\end{array}$} & & 9.799 & $<0.001^{*}$ \\
\hline & & & 18.555 & $<0.001^{*}$ \\
\hline \multirow{2}{*}{ CHL } & \multirow{2}{*}{ Total-CH Between Unweighed } & Groups & 1.797 & .168 \\
\hline & & & 3.581 & .060 \\
\hline \multirow{2}{*}{ LDL } & \multirow{2}{*}{$\begin{array}{l}\text { LDL Between Groups } \\
\text { Unweighed }\end{array}$} & & .945 & .390 \\
\hline & & & 1.884 & .171 \\
\hline \multirow{2}{*}{ HDL } & \multirow{2}{*}{$\begin{array}{l}\text { HDL Between Groups } \\
\text { Unweighed }\end{array}$} & & 1.764 & .174 \\
\hline & & & 1.456 & .229 \\
\hline \multirow{2}{*}{ VLDL } & \multirow{2}{*}{$\begin{array}{l}\text { VLDL Between Groups } \\
\text { Unweighed }\end{array}$} & & 9.420 & $<0.001^{*}$ \\
\hline & & & 17.757 & $<0.001^{*}$ \\
\hline \multicolumn{5}{|c|}{ Table 3: ANOVA Test } \\
\hline
\end{tabular}

* - Significant

\begin{tabular}{|c|c|c|c|c|}
\hline Dependent Variable & (I) grp & (J) grp & $\mathbf{t}$ & P value \\
\hline \multirow{4}{*}{ HbA1c } & \multirow{2}{*}{1.00} & 2.00 & 13.46 & $<0.001^{*}$ \\
\hline & & 3.00 & 23.50 & $<0.001^{*}$ \\
\hline & \multirow{2}{*}{2.00} & 3.00 & 9.49 & $<0.001^{*}$ \\
\hline & & & & \\
\hline \multirow{4}{*}{ TG } & \multirow{2}{*}{1.00} & 2.00 & 0.395 & 0.693 \\
\hline & & 3.00 & 4.241 & $<0.001^{*}$ \\
\hline & \multirow{2}{*}{2.00} & & & \\
\hline & & 3.00 & 2.423 & $0.017^{*}$ \\
\hline \multirow{4}{*}{ Total-CH } & \multirow{2}{*}{1.00} & 2.00 & 0.764 & 0.446 \\
\hline & & 3.00 & 1.884 & 0.061 \\
\hline & \multirow{2}{*}{2.00} & & & \\
\hline & & 3.00 & 0.668 & 0.506 \\
\hline \multirow{4}{*}{ LDL } & \multirow{2}{*}{1.00} & 2.00 & 0.530 & 0.597 \\
\hline & & 3.00 & 1.301 & 0.168 \\
\hline & \multirow{2}{*}{2.00} & & & \\
\hline & & 3.00 & 0.496 & 0.621 \\
\hline \multirow{4}{*}{ HDL } & \multirow{2}{*}{1.00} & 2.00 & 1.068 & 0.287 \\
\hline & & 3.00 & -1.165 & 0.247 \\
\hline & \multirow{2}{*}{2.00} & & & \\
\hline & & 3.00 & -1.806 & 0.074 \\
\hline \multirow{4}{*}{ VLDL } & \multirow{2}{*}{1.00} & 2.00 & 0.327 & 0.744 \\
\hline & & 3.00 & 4.162 & $<0.001^{*}$ \\
\hline & \multirow{2}{*}{2.00} & & & \\
\hline & & 3.00 & 2.448 & $0.016^{*}$ \\
\hline \multicolumn{5}{|c|}{ Table 4: Statistical Analysis - by 't' test } \\
\hline
\end{tabular}

* Significant

1.00 - control, 2.00 - under control, 3.00 - uncontrolled

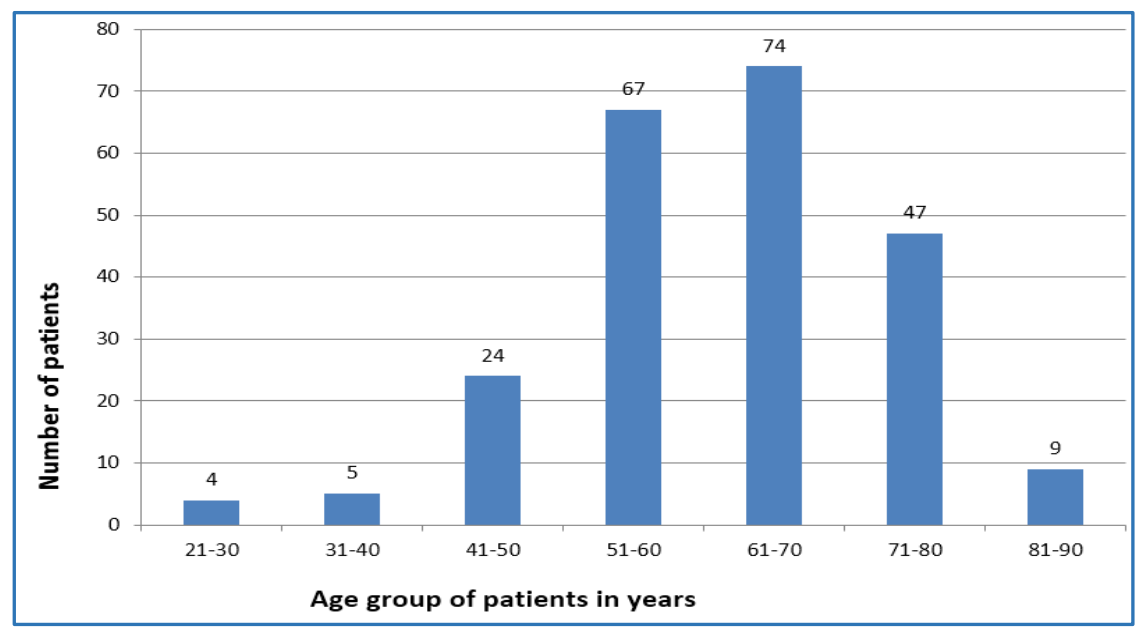

Fig. 1: Prevalence of HbA1c Patients in different Age Group 


\section{ACKNOWLEDGEMENT}

Many thanks to Dr Aruna Bhushan, Dr Shobha Karikatti, Mrs Sunanda for their help in statistics.

\section{REFERENCES}

1. IDF. International Diabetes Federation. Update 2014. Last retrieved on Nov 29, 2014.

2. Williams. Text book of Endocrinology. Philadelphia: Elsevier/Saunders, 2011;12 thed:1371-1436.

3. Shi Yuanki, Hu Frank B. The global implications of diabetes and cancer. The Lancet 2014;383(9933):19478.

4. Meena B, Kumar D, Singh VB, et al. Burden of disease study. Lancet 2010;380(9859):2163-96.

5. "About Diabetes" World Health Organization. Retrieved 4th April 2014.

6. Shoback, edited by David G Dolores. Greenspan's basic and clinical endocrinology. New York: McGraw-Hill. Medical; Chapter17, 2007; 9 thed:ISBN0-07-162243-8.

7. Diabetes fact sheet N0 312 World Health Organisation Oct 2013. Retrieved 25 March 2014.

8. O Gara PT, Kushner FG, Ascheim DD, et al. ACCF/AHA guidelines for the management of ST elevation myocardial infarction: a report of the American college of cardiology. Foundation/American heart association task force on practical guidelines. Circulation 2013;127(4):362-425.

9. Devrajani BR, Shah SZ, Soomro AA, et al. Type 2 diabetes mellitus: a risk factor for helicobacter pylori infection. A hospital based case control study. Int J Diabetes DevCtries 2010;30(1):22-26.

10. Roberto T, Dodesini AR, Lepore G. Lipid and disease. J Am Soc Nephrol 2006;17:145-47.

11. Friedewald WT, Levy RI, Fredrickson DS. Estimation of the concentration of low-density lipoprotein cholesterol in plasma, without use of the preparative ultracentrifuge. Clin Chem 1972;18:499-502.

12. Joshi SR, Parikh RM. India diabetes capital of the world now heading towards hypertension. J Assoc Physicians India 2007; 55:323-4.

13. Kumar A, Goel MK, Jain RB, et al. India towards diabetes control: key issues. Australas Med J 2013;6(10):524-31.

14. http://acpjc.acponline.org/Content/120/2/issue/ACPJ C-1994-120-2-0-1993 Intensive insulin therapy reduced microvascular and neurologic.

15. Holmann RR, Paul SK, Bethel MA, et al. Ten year followup of intensive glucose control in type 2 DM. N Engl J Med 2008;359(15):1577-89.
16. Nathan DM, Cleary PA, Backlund JY, et al. Intensive diabetes treatment and cardiovascular disease in patients with type 1 diabetes. $\mathrm{N}$ Engl J Med 2005;353(25):2643-53.

17. Nathan DM. DCCT/EDIC research group. The diabetes control and complications trial/epidemiology of diabetes interventions and complications study at 30 years: overview. Diabetes Care 2014;37(1):9-16.

18. Rohlfing CL, Weidmeyer HM, Little RR, et al. Defining the relationship between plasma glucose and HbA1c in the DCCT. Diabetic Care 2002;25:275-78.

19. Khan HA, Sobki SH, Khan SA. Association between glycaemic control and serum lipid profile in type 2 diabetic patients: HbA1c predicts dyslipidaemia. Clin Exp Med 2007;7:24-29.

20. Hidron AI, Edwards JR, Patel J, et al. NHSN annual update: antimicrobial resistant pathogens associated with health care associated infections: annual summary of data reported to the national healthcare safety network at the centre for disease prevention 20062007. Infect Control Hosp Epidemol 2007;29(11):9961011.

21. Khursheed MU, Bikharam D, Syed ZAS, et al. Lipid profile of patients with diabetes mellitus. World Appl Sci J 2011;12(9):1382-1384.

22. Ivy JL. Role of exercise training in the prevention and treatment of insulin resistance and NIDDM. Sports Medicine 1997;24(5):321-36.

23. Defronzo RA, Banting Lecture. From the triumvirate to the ominous octet a new paradigm for the treatment of type 2 diabetes mellitus. Diabetes 2009;58(4):773-95.

24. Joslin's. Diabetes mellitus: pathophysiology and treatment of lipid disorders in diabetes. SAE Wolters Kluwer/Lippincott William \& Wilkins 2005;14th ed:563572.

25. Howard BV, Robbins DC, Sievers ML, et al. LDL cholesterol as a strong predictor of coronary heart disease in diabetic individuals with insulin resistance and low LDL: the strong heart study. Arterioscler Thromb Vase Biol 2000;20:830-835. 